\title{
Investigation of the Compressive Strength and Curing Duration of Binary Blend of Groundnut Shell Ash Concrete
}

\author{
Umasabor, R. I. ${ }^{1, *}$ and Okovido, J. O. ${ }^{1}$ \\ ${ }^{1}$ Department of Civil Engineering, University of Benin, Benin City, Nigeria \\ Corresponding Author: *umasaborrichie@uniben.edu
}

\begin{abstract}
This paper studied the evaluation of the compressive strength of the binary blend of groundnut shell ash concrete and curing period. The purpose of the study was to source for local materials like agricultural waste that could replace some percentages of cement in order to make it more economical in concrete in order to ascertain its usefulness in the construction industry. An experimental (quantitative) method was adopted as the research design in this work. The total concrete specimens of size $100 \mathrm{~mm} \times 100 \mathrm{~mm}$ produced in the laboratory were one hundred and twenty (120). The groundnut shells were completely burnt in an electric furnace to obtain the ash and $0 \%$, $5 \%, 10 \%$ and $15 \%$ of the ashes were used to replace cement for a designed mix of concrete strength of $20 \mathrm{~N} / \mathrm{mm}^{2}$ at $\mathrm{w} / \mathrm{c}$ ratio of 0.6 , after varying the $w / \mathrm{c}$ ratios from 0.4 to 1.0, according to basic guidelines stated in Department of Environment method. They were cured at 7 days, 28 days, 30 days, 60 days, 90 days, 120 days, 150 days and 200 days. The concrete cubes were taken to the compression machine for compression test. The result shows that compressive strength of the groundnut shell ash concrete increases as the curing period increases and there was decrease in the compressive strength of the pozzolanic concrete as the percentages of groundnut shell ash increases in the concrete. The binary blend of groundnut shell ash at 5\% replacement had the maximum compressive strength of $23.3 \mathrm{~N} / \mathrm{mm}^{2}$ at 200 days while the control concrete compressive strength was $22.0 \mathrm{~N} / \mathrm{mm}^{2}$. This represents an increment of $1.06 \%$ of compressive strength over the control at 200 days.
\end{abstract}

Keywords: Pozzolans, compressive strength, blended concrete, curing duration, replacement

\subsection{Introduction}

Groundnut shell is an agricultural waste obtained from milling of groundnut. About $5 \%$ of ash is obtained when the shells are oxidized by burning (Oriola and Moses, 2010). Nigeria contributes about 7 percent of world groundnut production which makes Nigeria the 3rd largest producer of groundnut in the world (Oriola and Moses, 2010).

Oriole and Moses (2010) investigated the effect of groundnut shell ash in stabilization of black cotton soil. They found no improvement on the soil. Adole et al. (2011) studied the effect of groundnut husk ash (GHA) blended cement on chemical resistance of concrete. The authors cured the specimen with $\mathrm{MgSO}_{4}, \mathrm{NaCl}$ and $\mathrm{H}_{2} \mathrm{SO}_{4}$ at 14, 21 and 28 days. The results revealed that Ordinary portland cement/ groundnut husk ash (OPC/GHA) performed best in most of the chemical solutions at 28 days hydration period with compressive strength value of $21.0 \mathrm{~N} / \mathrm{mm}^{2}$ in $\mathrm{MgSO}_{4}$ solution and $22.55 \mathrm{~N} / \mathrm{mm}^{2}$ in $\mathrm{NaCl}$ solution. Nwofor and Sule (2012) worked on the stability of groundnut shell ash (GSA)/ ordinary Portland cement (OPC) concrete in Nigeria. They found out that $10 \%$ replacement of cement with GSA is suitable for sustainable construction especially in mass concrete construction. Umasabor (2009) also studied partial replacement of ordinary Portland cement (OPC) with groundnut shell ash (GSA) in concrete and discovered that $10 \%$ replacement of cement with GSA in concrete will be more suitable. 
The inclusion of eco-friendly materials into OPC mixes originated from the rising concern and worries over environmental degradations such as global warming, atmospheric pollutions and waste disposals (Mohammed et al., 2011). These coupled with the recent worldwide economic recession have indeed strengthened the inspiration for the continuous efforts towards the search for durable and sustainable infrastructures (Walter et al., 2004; Dionys, 2007). As a result of urbanization, huge amount of carbon dioxide $\left(\mathrm{CO}_{2}\right)$ and carbon monoxide $(\mathrm{CO})$ are produced and thus affecting various civil engineering structures which go through temperature changes (Milon et al., 2012).

Presently, pozzolans from agricultural waste are receiving more attention since their utilization do not only improve the properties of the blended cement concrete but also reduce the environmental problems (Chindaprasirt et al., 2008). Economics and environmental considerations also have a role in the growth of mineral admixture usage. The lower cement requirement leads to a reduction in the amount of carbon dioxide generated by the production of cement and hence its emission to atmosphere (Toutanji et al., 2004). The addition of wide range of blending material also introduces significant diversity into the cementing system.

Pozzolans in concrete below 50 days have strength below normal concrete but above 50-90 days strength development is beyond normal concrete (Ettu, 2013).This study will focus on when compressive strength development stops. A confirmation of increase in compressive strength of concrete due to addition of agricultural waste ashes in concrete would introduce high demand for agricultural waste ashes for concrete use.

\subsection{Materials and Methods}

The study uses the experimental (quantitative) research design method to carry out this work. The laboratory work includes the experimental group and the control group. The experimental group contains the groundnut shell ash in 5\%,10\% to $15 \%$ replacement of cement in concrete called the pozzolanic group while the control group contains only the ordinary Portland cement in concrete called the Ordinary portland cement (OPC) control group. The experimental design is concerned about the examination of the effect of curing periods (independent variable) on the compressive strength (dependent variable) of the pozzolanic group and the OPC control group.

The material used in the tests comprises groundnut shell ash, Portland cement, 20mm crushed coarse aggregate, fine aggregate and water. The tools used consisted of steel moulds (100mmx100mm size), shovel, head pans and muffle electric furnace. $100 \mathrm{~mm} \times 100 \mathrm{~mm}$ steel moulds were used due to its availability of the quantity required for the test in the Civil Engineering Laboratory, University of Benin, Benin City. The groundnut shells were obtained in Auchi, Edo state.

The ash was obtained by controlled burning of the rice husk with the help of a muffle furnace until the ash was produced at $400^{\circ} \mathrm{C}$ for 2 hours. The burnt ash was sieved through British Standard sieve of 75 microns after grinding. The portion passing the sieve was adequate for the required degree of fineness that is 63 microns and below while the ash retained on the sieve were reground and sieved again. The preparation of the test specimens follows the procedure as outlined by appropriate British Standards especially BS 1881: 124 (1988). Setting time of the various mortar pastes were also carried out.

Trial mixes were made according to the procedure in BS 1881: Part 1 (2001) and the compressive strength tests on the concrete were carried out in accordance with BS 1881; Part 2, Part 3 and Part 4 (2001).

\subsection{Population}

The number of specimen produced for both the pre-test and post-test experiments were fifty six (56) concrete specimen and one and sixty four (64) concrete specimen respectively totaling one hundred and twenty concrete specimen altogether (120) of size $100 \mathrm{~mm}$ x $100 \mathrm{~mm}$. 


\subsection{Data Source}

Data were sourced from various laboratory test conducted which includes the chemical analysis of GSA and OPC, specific gravity test, slump test, bulk density test, setting time test, compressive strength test respectively.

\subsection{Results and Discussion}

\subsection{Chemical Analysis of Pozzolans Using X-Ray Fluorescence (XRF)}

Chemical analysis was carried out on samples of groundnut shell ash (GSA) and ordinary Portland cement (OPC) to reveal and compare their composition, and the results are shown in Table 1 . The percentage compositions of the constituent compounds in groundnut shell ash (GSA) are compared to compounds known to have binding properties necessary for concrete work. GSA has total percentage Iron Oxide $\left(\mathrm{Fe}_{2} \mathrm{O}_{3}\right)$, Silicon Dioxide $\left(\mathrm{SiO}_{2}\right)$ and Aluminum Oxide $\left(\mathrm{Al}_{2} \mathrm{O}_{3}\right)$ of $43.87 \%$, which is less than the required minimum of $70 \%$ according to America Society for Testing and Material (ASTM) C618 (2005).

Table 1: Chemical composition of OPC and GSA pozzolan (\%)

\begin{tabular}{cccc}
\hline \multirow{2}{*}{$\mathrm{S} / \mathrm{N}$} & Elemental Oxides & GSA & OPC \\
\cline { 3 - 4 } & & 35.70 & 22.0 \\
2 & Silica $\left(\mathrm{SiO}_{2}\right)$ & 13.14 & 0.4 \\
3 & Potassium oxide $\left(\mathrm{K}_{2} \mathrm{O}\right)$ & 7.08 & 62.0 \\
4 & Calcium oxide $(\mathrm{CaO})$ & 6.77 & 5.03 \\
5 & Alumnium oxide $\left(\mathrm{Al}_{2} \mathrm{O}_{3}\right)$ & 5.68 & 2.06 \\
6 & Magnesium oxides $(\mathrm{MgO})$ & 1.40 & 4.65 \\
7 & Iron oxide $\left(\mathrm{Fe}_{2} \mathrm{O}_{3}\right)$ & 2.24 & 0.19 \\
8 & Sodium oxide $\left(\mathrm{Na}_{2} \mathrm{O}\right)$ & 1.20 & 2.06 \\
9 & Manganese oxide $(\mathrm{MnO})$ & 0.04 & 0.93 \\
10 & Sulphite $\left(\mathrm{SO}_{3}\right)$ & 0.46 & 0.95 \\
11 & Titanium oxide $\left(\mathrm{TiO}_{2}\right)$ & 1.06 & 20.22 \\
\hline
\end{tabular}

\subsection{Specific Gravity Test}

The specify gravity test conducted on the pozzolanic material shows that the specific gravity of GSA is 0.84 in Table 2. This value is less than the value for OPC which is 3.15. This means that GSA material is lighter than OPC. However, the specific gravity of sand and granite were found to be 2.65 and 2.70 respectively.

Table 2: Determination of specific gravity of GSA Pozzolans

\begin{tabular}{ccccccccccc}
\hline Sample & B+W & B+S+W & B+S & B & Ad. W & WWAS & WS & WOWDS & Gs & AGs \\
\hline 1 & 69.01 & 67.39 & 29.65 & 19.49 & 49.52 & 37.74 & 10.16 & 11.78 & 0.86 & \\
\cline { 1 - 7 } 2 & 69.89 & 67.62 & 31.93 & 21.08 & 48.81 & 35.69 & 10.85 & 13.12 & 0.83 &
\end{tabular}

Notes: $B+W=W t$. of Bottle +Water (full) W4; B+S+W=Wt. of Bottle + Soil + Water W3; B+S $=$ Wt. of Bottle + Soil W2; B $=$ Wt. of Bottle W1; Ad.W =Wt. of Added Water (full) $(W 4-W 1) ; W W A S=W t$. of Water added to Soil $(W 3-W 2) ; W S=W t$. of Soil $(W 2-W 1) ; W O W D S=W t$. of Water Displaced by Soil $(W 4-W 1)-(W 3-W 2)=W ; G_{S}=$ Specific Gravity $(W 2-W 1) / W ; A G_{S}=$ Average Specific Gravity $\left(G_{S} / 2\right)$ 


\subsection{Densities of the Binary Blended Concrete}

The densities of the binary blended concrete are presented in Table 3. Densities increased as curing ages increased for all the binary blended concrete.

Table 3: Density of ternary and binary blended concrete for GSA and RHA pozzolans

\begin{tabular}{ccccc}
\hline \multirow{2}{*}{ Age of Curing (Days) } & \multicolumn{4}{c}{ Densities $\left(\mathrm{Kg} / \mathrm{m}^{3}\right)$} \\
\cline { 2 - 4 } & $0 \%(\mathrm{OPC})$ & $5 \%(\mathrm{GSA})$ & $10 \%(\mathrm{GSA})$ & $15 \%$ (GSA) \\
\cline { 2 - 4 } & 2375 & 2375 & 2330 & 2260 \\
30 & 2360 & 2390 & 2355 & 2325 \\
60 & 2390 & 2410 & 2395 & 2340 \\
90 & 2400 & 2430 & 2410 & 2350 \\
120 & 2385 & 2445 & 2370 & 2345 \\
150 & 2365 & 2450 & 2535 & 2485 \\
\hline
\end{tabular}

\subsection{Compressive Strengths of Binary Blended Concrete and OPC at Different Curing Ages}

Compressive strength of concrete increases as the curing ages increases for all the percentages of cement replacement with pozzolan in concrete as shown in Table 4 and Figure 1. Its result has shown that binary replacement of cement with GSA pozzolan can be possible up to 15\% replacement in concrete, when cured for up to 200 days.

Table 4: Relationship between compressive strength and curing age of GSA pozzolan at $23^{\circ} \mathrm{C}$

\begin{tabular}{|c|c|c|c|c|}
\hline \multirow{2}{*}{$\begin{array}{c}\text { Age of Curing } \\
\text { (Days) }\end{array}$} & \multicolumn{4}{|c|}{ Compressive Strength $\left(\mathrm{N} / \mathrm{mm}^{2}\right)$} \\
\hline & $5 \%$ GSA & $10 \%$ GSA & $15 \%$ GSA & Control (OPC) \\
\hline 7 & 7.6 & 6.4 & 5.5 & 9.4 \\
\hline 28 & 13.1 & 12.1 & 11.7 & 14.1 \\
\hline 30 & 18.0 & 16.0 & 12.5 & 16.0 \\
\hline 60 & 18.5 & 16.5 & 14.0 & 16.5 \\
\hline 90 & 19.5 & 16.5 & 15.0 & 18.5 \\
\hline 120 & 21.0 & 17.5 & 16.0 & 18.5 \\
\hline 150 & 22.1 & 17.8 & 19.0 & 19.5 \\
\hline 200 & 23.3 & 19.1 & 21.8 & 22.0 \\
\hline
\end{tabular}

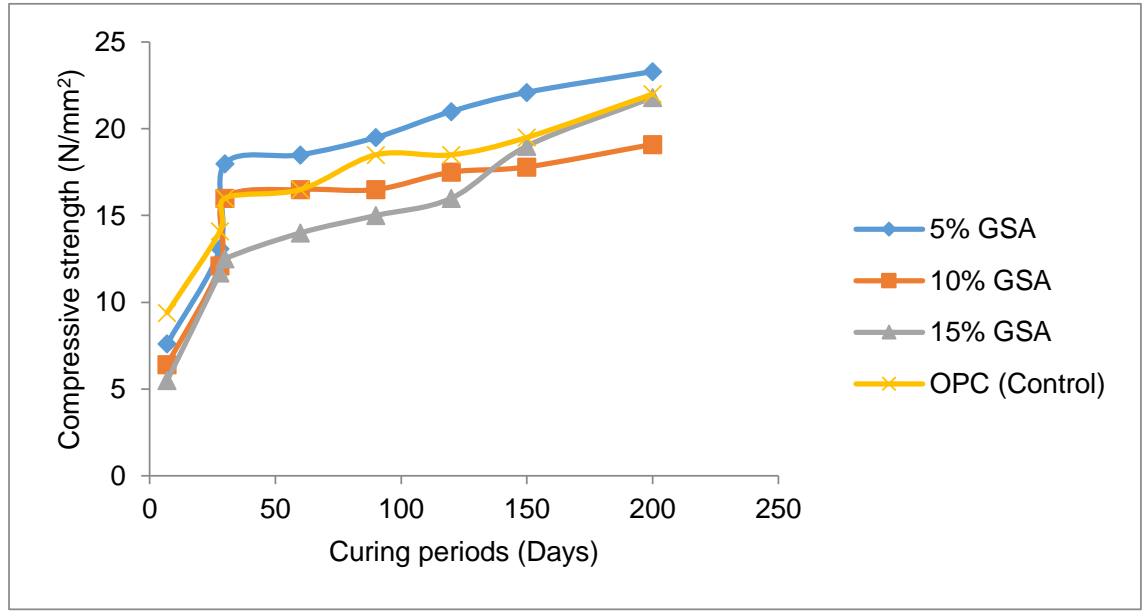

Figure 1: Relationship between compressive strength and curing period at 0\%-15\% GSA replacement 
However, 5\% GSA blended concrete strength increase started at 90 days of curing with a compressive strength of $21.0 \mathrm{~N} / \mathrm{mm}^{2}$. At $10 \%$ GSA replacement with OPC, the strength was equal at 60 days of curing with OPC concrete with a compressive strength of $16.0 \mathrm{~N} / \mathrm{mm}^{2} .15 \%$ of GSA blended concrete started its strength increase from 200 days with compressive strength of $21.8 \mathrm{~N} / \mathrm{mm}^{2}$. The trend of results obtained from this study collaborate findings of earlier studies by Englehardt et al. 1995 that pozzolanlime reactions are usually slow, starting after one or more weeks and that the behavior of the delay in pozzolanic reaction will result in more permeable concrete at early ages and gradually becomes denser than plain concrete with time. The effect of the pozzolanic reaction produces more cement gel (i.e. C$\mathrm{S}-\mathrm{H}$ and C-A-H) reducing the pore size, blocks the capillary and produces denser concrete thus making it stronger and more durable (Ayantoyinbo, 2011).

However, the binary blend of groundnut shell ash at 5\% replacement had the maximum compressive strength of $23.3 \mathrm{~N} / \mathrm{mm}^{2}$ at 200 days while the control concrete compressive strength was $22.0 \mathrm{~N} / \mathrm{mm}^{2}$. This represents an increment of $1.06 \%$ of compressive strength over the control concrete at 200 days of curing. This depicts what Ettu, 2013 said that pozzolans in concrete below 50 days has strength below normal concrete but above 50-90 days strength development is beyond normal concrete.

\subsection{Conclusions}

The following conclusions can be made from this study:

1. The agricultural ash used in this work which was groundnut shell ash (GSA) is reasonably pozzolanic since they contain silica which reacts with calcium to produce extra calcium silicate hydrate $(\mathrm{C}-\mathrm{S}-\mathrm{H})$ paste which is the strength compound of concrete.

2. The compressive strength values of the groundnut shell ash (GSA) concrete consistently increases as the curing period increases.

3. The 200 days compressive strength of 5\% GSA and 95\% OPC binary blended cement concrete gave the optimum value of $23.3 \mathrm{~N} / \mathrm{mm}^{2}$ which is $1.06 \%$ higher in compressive strength to the OPC concrete.

4. OPC can be replaced with GSA pozzolan up to $15 \%$ in the binary blended cement concrete of grade 20 when cured up to 200 days without reducing its compressive strength.

5. This work has provided a database on the effect of groundnut shell ash pozzolan on the compressive strength of concrete subjected to long-duration of curing.

\section{References}

Adole, M.A., Dzasu, W.E, Umar, A. and Oraegbune, O.M., (2011), "Effects of Chemicals on the Properties of Concrete with Cement Partially Replaced with Groundnut Husk Ash (GHA)" ATBU Journal of Environmental Technology. Vol.4, No.1, pp.23-32

ASTM C618 (2005), "Specification for Fly Ash and Raw or Calcium Natural Pozzolana for use as a Mineral Admixture in Portland Cement Concrete". American Standard for Testing Materials

Ayantoyinbo, Y.T. (2011), "Effect of the Partial Replacement of Cement by some Pozzolanic Agricultural Waste Ash on the Compressive Strength of Concrete." Unpublished M.Eng Project in Civil Egineering Department, University of Benin

BS1881 (2001), "Testing on Concrete: Guide on the use of Non-Destructive Methods of Test for Hardened Concrete" United Kingdom

BS 1881: Part 124 (1988) 'Methods of Analysis of Hardened Concrete'. Her Majesty's Stationary Office: London, United Kingdom. 
Chindaprasirt. P, Rukzon. S and Sirivivatnanon V. (2008), " Resistance to Chloride Penetration of Blended Portland Cement Mortar Containing Palm Oil Fuel Ash, Rice Husk Ash and Fly Ash". Journal of Construction Building Materials, Vol.22, pp.932-938.

Dionys, V.G (2007), "Cement-Concrete and Concrete-Polymer Composites: Two Merging

Worlds" 12th international Congress on Polymers in Concrete (ICPIC). Chuncheon, Korea; September 27-28. pp. 3-15.

Englehardt, J. D and Peng, C. (1995), "Pozzolanic Filtration and Solidification of Radio- nuclides in Nuclear Reactor Cooling Water, Journal of Waste Management Vol.15, No.8, pp.585- 592.

Ettu,O.L(2013), “Strength Characteristics of Blended Cement Composites” Unpublished Ph.D Thesis in Federal University of Technology, Owerri.

Milon, K., Howlader, M. H., Rashid, D. M. and Tozammel, H. (2012), "Effect of Aggregate Types on Thermal Properties of Concrete" Journal of Engineering and Applied Sciences. Vol.7, No.7, pp.900907

Mohammad, I., Mohamed, E. I. and Bala, M. (2011), "Influence of Elevated Temperatures on Physical and Compressive Strength Properties of Concrete Containing Palm Oil Fuel Ash" Journal of Construction and Building Materials. Vol.25, pp.2358-2364

Nwofor, T.C. and Sule, S. (2012), " Stability of Groundnut Shell Ash (GSA)/Ordinary Portland Cement (OPC) Concrete in Nigeria", Advances in Applied Science Research. Vol.3, No.4, Okere, C.E. (2012), "Structural Characteristics of Soilcrete Blocks (Unpublished Doctoral Dissertation). Federal University of Technology Owerri, Nigeria.

Oriola, F. and Moses, G. (2010), "Groundnut Shell Ash Stabilisation of Black Cotton Soil" Environmental Journal of Geotechnical Engineering, Vol.15, pp.415-428.

Toutanji H, Delatte N, Aggoun S, Duval R, Danson A. (2004) " Effect of Supplementary Cementatious Materials on Compressive Strength and Durability of Short Term Cured Concrete". Cement and Concrete Research, Vol. 34, pp. $311-319$

Umasabor, R.I. (2009), "The Partial Replacement of Ground Shell Ash with Cement in Concrete" M.Eng Thesis submitted in Civil Engineering Department, University of Benin, Benin City.

Walter, O.O., Kunitomo, S. and Eiichi, W. (2004), "Flexural Response of Polymer Concrete Filled Steel Beams" Journal of Construction Building Materials, Vol.18 pp.367-376. 